\title{
4-isothiocyanate-2, 2, 6, 6-tetramethyl piperidinooxyl inhibits angiogenesis by suppressing VEGFR2 and Tie2 phosphorylation
}

\author{
YUANYUAN LIU ${ }^{1,2^{*}}$, JING GAO $^{3 *}$, SHUANGSHENG HUANG ${ }^{3}$, LAMEI HU ${ }^{1}$, ZHIQIANG WANG ${ }^{1}$, \\ ZHEYUAN WANG $^{4}$, XIAO CHEN $^{4}$, XIAOYU ZHANG $^{1}$ and WENGUANG LI ${ }^{1}$ \\ ${ }^{1}$ College of Basic Medicine, Key Laboratory of Preclinical Study for New Drugs of Gansu, Lanzhou University; \\ ${ }^{2}$ Institute of Modern Physics, Chinese Academy of Sciences, Lanzhou, Gansu 730000; \\ ${ }^{3}$ Clinical Laboratory, Affiliated Hospital of Medical College of Northwest University for Nationalities; \\ ${ }^{4}$ Department of General Surgery, Second Hospital of Lanzhou University, Lanzhou, Gansu 730030, P.R. China
}

Received June 25, 2015; Accepted July 20, 2016

DOI: $10.3892 / 01.2016 .4948$

\begin{abstract}
Reactive oxygen species (ROS) are involved in the signaling pathway and are triggered by angiogenic factors, including vascular endothelial growth factor and angiopoietins. 4-isothiocyanate-2, 2, 6, 6-tetramethyl piperidinooxyl (4-ISO-Tempo) is one of the nitroxides that exhibits antioxidant activity. However, the anti-angiogenic effect of 4-ISO-Tempo remains unknown. The aim of this study was to investigate the effect of 4-ISO-Tempo on tumor proliferation and angiogenesis as well as its underlying mechanisms. Our results revealed that 4-ISO-Tempo significantly inhibited the viability of neoplastic and endothelial cells. Furthermore, the effective concentration of 4-ISO-Tempo on human microvascular endothelial cell 1 (HMEC-1) was lower than that on human lung adenocarcinoma A549 and human colon cancer SW620 cells. This suggested that endothelial cells were more sensitive to 4-ISO-Tempo than tumor cells. Furthermore, we demonstrated that 4-ISO-Tempo also suppressed secretion of matrix metalloproteinase (MMP)-2 and MMP-9, and migration and tube formation of HMEC-1 cells. The mechanism is attributed to the decreasing ROS generation and further phosphorylation of vascular endothelial growth factor receptor 2 and Tie2. Our findings suggest that 4-ISO-Tempo should be investigated for its usefulness in anti-angiogenesis therapies.
\end{abstract}

Correspondence to: $\mathrm{Dr}$ Wenguang Li, College of Basic Medicine, Key Laboratory of Preclinical Study for New Drugs of Gansu, Lanzhou University, 199 Donggang West Road, Lanzhou, Gansu 730000, P.R. China

E-mail: liwg@lzu.edu.cn

${ }^{*}$ Contributed equally

Key words: 4-isothiocyanate-2, 2, 6, 6-tetramethyl piperidinooxyl, angiogenesis, reactive oxygen species, vascular endothelial growth factor receptor 2 , Tie2

\section{Introduction}

The development of a vascular network is considered to be a rate-limiting step for tumor growth, invasion and metastasis (1). Tumor angiogenesis is defined as the formation of new capillary from pre-existing vessels. Early studies demonstrated that microvessel density, a measure of angiogenesis, was highly correlated with poorer survival in primary breast, prostate, gastric, non-small cell lung and cervical cancers (2-4). Therefore, tumor angiogenesis is a promising target for the treatment of solid cancers. A number of growth factors and inflammatory cytokines are known to promote angiogenesis, including vascular endothelial growth factor (VEGF), angiopoietins (Angs) and interleukin-8 (5-7). Among these, VEGF is one of the most significant pro-angiogenic factors, which binds to kinase insert domain-containing receptor (KDR/FLk-1/VEGFR2), particularly expressed in endothelial cells, to mediate its angiogenic effect (8). Accumulating evidence has revealed that VEGF stimulates autophosphorylation of VEGF receptor 2 (VEGFR2) and then initiates the signaling cascade involving the PKC-Raf1-MEK-ERK1/2 and PI-3K/AKT/eNOS pathways to exert angiogenic and pro-survival effects on endothelial cells $(9,10)$. Subsequently, inhibition of VEGFR2 signaling by small molecule inhibitors was demonstrated to significantly suppress the growth of a variety of solid tumors (11). In addition, bevacizumab, a neutralizing antibody to VEGF, has been applied to prolong survival in patients with malignant colon cancer, and is currently being tested with other tumor types (12).

However, new blood vessels stimulated by VEGF alone are not mature. Angiopoietin 1 (Ang1) is another significant pro-angiogenic factor. Unlike VEGF, Ang1 is required for vascular remodeling and maturation during angiogenesis. After binding to its receptor Tie2, Ang1 stimulates autophosphorylation of Tie2 and then activates downstream signaling molecules, including AKT and ERK, which promotes stabilization of the immature endothelial cell network (13). It is generally accepted that VEGF/VEGFR2 signaling is essential for new blood vessel formation, while Ang1/Tie2 signaling is critical for blood vessel maturation and stabilization. Therefore, the inhibition of the two pathways exhibits additive anti-angiogenic effects. 
Accumulating evidence has indicated that masses of reactive oxygen species (ROS) induce cell death, while low concentrations of ROS play a crucial role in tumor progression by acting as a signaling molecule $(14,15)$. ROS are also involved in the processes of angiogenesis, including proliferation, degradation of the extracellular matrix, migration, and differentiation of endothelial cells. A number of antioxidants exhibit anti-angiogenic activity.

The nitroxides are a group of metal-free, low molecular weight, water-soluble and stable free radicals which are widely used in electron paramagnetic resonance spectroscopy $(16,17)$. Increasing evidence has revealed that nitroxides have antioxidative and anticancer activity. Gariboldi et al also demonstrated that treatment with nitroxide decreased the rate of tumor vascularization and reduced microvessel density (18). 4-isothiocyanate-2,2,6,6-tetramethyl piperidinooxyl (4-ISO-Tempo) is one of the nitroxides that exhibits significant antioxidant activity. However, the anti-neoplastic and anti-angiogenic effect of 4-ISO-Tempo has yet not been reported. The main aim of the present study was to investigate the anti-angiogenic activity of 4-ISO-Tempo and its underlying molecular mechanism.

\section{Materials and methods}

Materials and reagents. 4-ISO-Tempo was a gift from the State Key Laboratory of Applied Organic Chemistry, Lanzhou University (Lanzhou, China). It was dissolved in dimethylsulfoxide. MCDB131 medium, epidermal growth factor (EGF), hydrocortisone, sulforhodamine B (SRB) sodium salt, gelatin and 2',7'-Dichlorofluorescin diacetate (DCFH-DA) were purchased from Sigma-Aldrich (St. Louis, MO, USA). Leibovitz's L-15 medium and Dulbecco's modified Eagle's medium (DMEM) were purchased from Gibco Life Technologies (Carlsbad, CA, USA). Fetal bovine serum (FBS) was purchased from Lanzhou HyClone (Lanzhou, China). Matrigel was purchased from Becton Dickinson (Bedford, MA, USA). Millicell cell culture inserts were purchased from Millipore (Bedford, MA, USA). Recombinant human VEGF and recombinant human Ang1 were purchased from Peprotech (Rocky Hill, NJ, USA). Antibodies to VEGFR2, Tie2 and actin were purchased from Santa Cruz Biotechnology (Santa Cruz, CA, USA). Phospho-VEGFR2 (Tyr 1175) rabbit mAb and Phospho-Tie2 (Tyr 992) antibody were purchased from Cell Signaling Technology (Beverly, MA, USA). Other agents were of analytical purity.

Cell line and cell culture. Human microvascular endothelial cells (HMEC-1) were cultured in MCDB131 medium containing $20 \% \mathrm{FBS}, 10 \mathrm{ng} / \mathrm{ml} \mathrm{EGF}$ and $1 \mu \mathrm{g} / \mathrm{ml}$ hydrocortisone. Human colon carcinoma cells (SW620) were cultured in Leibovitz's L-15 medium supplemented with $10 \%$ FBS. Human lung adenocarcinoma cells (A549) were cultured in DMEM with $10 \%$ FBS. Cells were incubated in an atmosphere of $5 \% \mathrm{CO}_{2}$ at $37^{\circ} \mathrm{C}$.

Cell viability assay. The effect of 4-ISO-Tempo on the viability of various cell lines was examined with SRB assay $(19,20)$. Briefly, HMEC-1, SW620 and A549 cells were seeded in 96-well plates. Following overnight incubation, the cells were treated with or without 4-ISO-Tempo for 24 and $72 \mathrm{~h}$. The culture medium was then discarded. $10 \%$ trichloroacetic acid $(100 \mu \mathrm{l})$ was added to each well and the plates were incubated at $4^{\circ} \mathrm{C}$ for $1 \mathrm{~h}$. Each well was stained with $100 \mu \mathrm{l} 0.4 \% \mathrm{SRB}$ for $30 \mathrm{~min}$, washed with $1 \%$ acetic acid to remove unbound dye and left to dry overnight. The protein-bound SRB dye was solubilized with $100 \mu 110 \mathrm{mM}$ Tris base. The optical density in each well was read with a microplate reader (Infinite® 200 PRO series; Tecan Group Ltd., Männedorf, Switzerland) at $515 \mathrm{~nm}$.

Gelatin zymography. Matrix metalloproteinase (MMP)-2 and MMP-9 gelatinase activity was measured as described in a previous study (21) with slight modification. HMEC-1 cells were treated with various concentrations of 4-ISO-Tempo in the absence of serum for $24 \mathrm{~h}$ at $37^{\circ} \mathrm{C}$. The conditioned medium was collected and centrifuged. Supernatant was collected and separated by $7.5 \%$ sodium dodecyl sulphate (SDS) polyacrylamide gel containing $1 \%$ gelatin. Then the gels were washed for $1 \mathrm{~h}$ at room temperature to remove SDS and incubated in the incubation buffer [50 mM Tris- $\mathrm{HCl}(\mathrm{pH} 7.5), 0.2 \mathrm{M} \mathrm{NaCl}$ and $5 \mathrm{mM} \mathrm{CaCl}_{2}$ ] for $36 \mathrm{~h}$ at $37^{\circ} \mathrm{C}$. The gel was stained for $1 \mathrm{~h}$ with $0.5 \%$ Coomassie brilliant blue R-250 and destained with $25 \%$ methanol and $7.5 \%$ acetic acid. Gelatinase activity was detected as clear bands against a dark blue background.

Cell migration assay. Endothelial cell migration assay was measured as described previously (19) with slight modification. Briefly, 2x10 ${ }^{5}$ HMEC-1 cells in serum-free culture medium with or without 4-ISO-Tempo were added into the upper chamber cell culture inserts. The lower chamber contained $600 \mu \mathrm{l}$ MCDB131 medium supplemented with $20 \%$ FBS. Following incubation for $24 \mathrm{~h}$, non-migrated cells were scraped with a cotton swab. The bottom side of the membrane was fixed by ethanol and then stained with $0.1 \%$ crystal violet. The migrated cells were then washed three times with phosphate-buffered saline (PBS). Images of at least five randomly selected microscopic fields were captured under light microscopy. The number of migrated cells was counted using ImagePro Plus software (Media Cybernetics, Inc., Rockville, MD, USA).

Tube formation assay. Tube formation assay was measured as described previously (19) with slight modification. HMEC-1 cells at a density of $8 \times 10^{4} /$ well were seeded in Matrigel-coated 96-well plates in MCDB131 medium containing various concentrations of 4-ISO-Tempo. After $8 \mathrm{~h}$, images were captured under an inverted microscope (Olympus IX41; Olympus Corporation, Tokyo, Japan) and the tubular length was measured using ImagePro Plus software.

Western blot assay. Western blot assay was assessed as previously described (22) with slight modification. HMEC-1 cells were pretreated with various concentrations of 4-ISO-Tempo for $24 \mathrm{~h}$ and then stimulated with $50 \mathrm{ng} / \mathrm{ml}$ VEGF for $10 \mathrm{~min}$ or $200 \mathrm{ng} / \mathrm{ml} \mathrm{Ang1} \mathrm{for} 30 \mathrm{~min}$. Cells were lysed in lysis buffer with proteinase inhibitors $\left(50 \mathrm{mM} \mathrm{NaF}, 0.2 \mathrm{mM} \mathrm{Na} \mathrm{VO}_{4}\right.$, $1 \mathrm{mM}$ phenylmethane sulfonyl fluoride, $2 \mu \mathrm{g} / \mathrm{ml}$ aprotinin and $2 \mu \mathrm{g} / \mathrm{ml}$ leupeptin). Equal amounts of protein for each sample were separated by SDS polyacrylamide and transferred onto the polyvinylidene fluoride membrane. The membrane was 
A
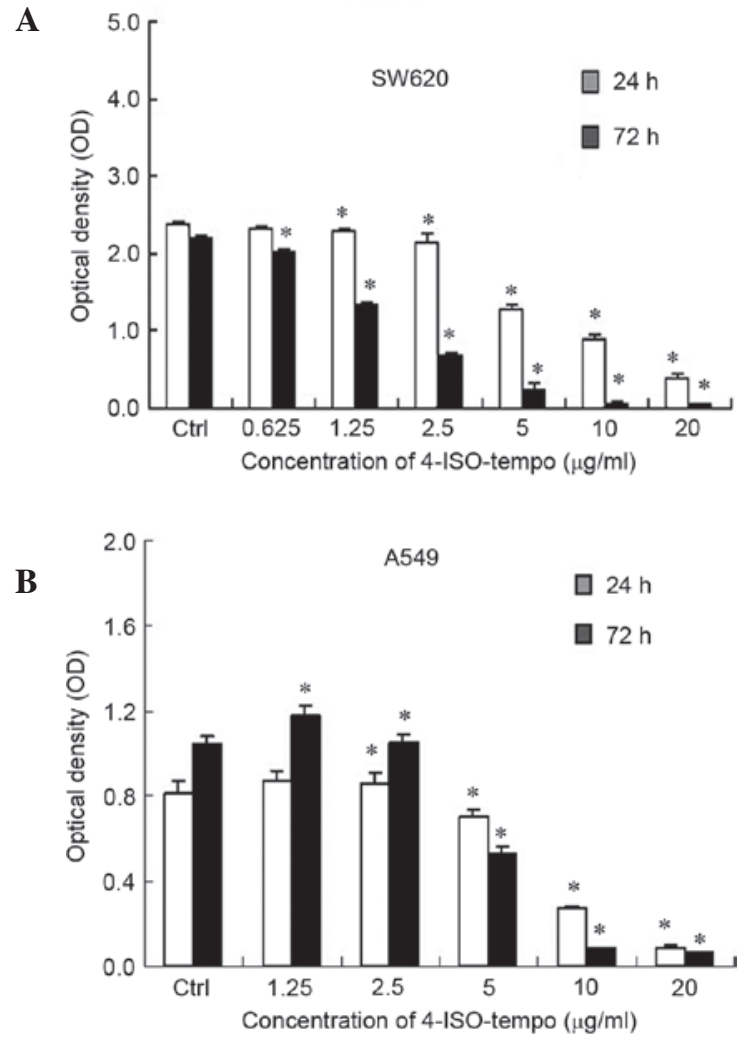

Figure 1. 4-ISO-Tempo significantly inhibits cell viability of (A) SW620 and (B) A549 cells. All data are expressed as the means \pm standard error from three independent experiments. "P $<0.05$ vs. control. 4-ISO-Tempo, 4-isothiocyanate-2, 2, 6, 6-tetramethyl piperidinooxyl.

then blocked and probed with specific antibodies. Horseradish peroxidase-conjugated secondary antibodies were used to probe the antibody. Immunoreactive bands were detected with chemiluminescence.

Intracellular ROS measurement. The intracellular ROS were measured as described previously (23) with slight modification. HMEC-1 cells were seeded in a six-well plate and treated with 4-ISO-Tempo in serum-free medium for $4 \mathrm{~h}$. Then the cells were left untreated or treated with $50 \mathrm{ng} / \mathrm{ml} \mathrm{VEGF}$ for $10 \mathrm{~min}$ and incubated with $10 \mu \mathrm{M}$ DCFH-DA for $30 \mathrm{~min}$. The cells were washed twice with PBS and the fluorescent images were captured under a contrast fluorescence microscope (Olympus BX51; Olympus Corporation). The fluorescent intensity was measured using ImagePro Plus software.

Statistical analysis. Data are expressed as the means \pm standard error. Statistical significance was evaluated using Student's t-test. $\mathrm{P}<0.05$ was considered to indicate a statistically significant difference.

\section{Results}

Effect of 4-ISO-Tempo on tumor cell viability. SW620 and A549 cells were sensitive to 4-ISO-Tempo. As shown in Fig. 1, 4-ISO-Tempo demonstrated a significant inhibitory effect on the viability of SW620 and A549 cells in a dose-dependent manner following $72 \mathrm{~h}$ treatment, with an $\mathrm{IC}_{50}$ value of $1.742 \mu \mathrm{g} / \mathrm{ml}$ for SW620 cells and $5.550 \mu \mathrm{g} / \mathrm{ml}$ for A549 cells.

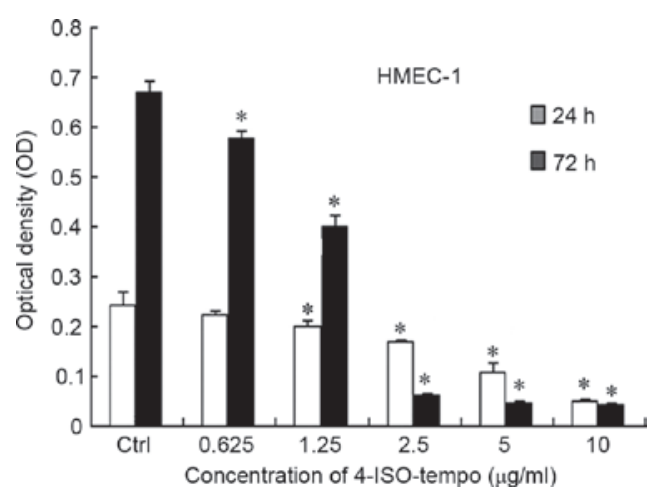

Figure 2. 4-ISO-Tempo significantly inhibits cell viability of endothelial cells. All data are expressed as the means \pm standard error from three independent experiments. ${ }^{*} \mathrm{P}<0.05$ vs. control. 4-ISO-Tempo, 4-isothiocyanate- 2 , 2, 6, 6-tetramethyl piperidinooxyl. HMEC-1, human microvascular endothelial cell 1.

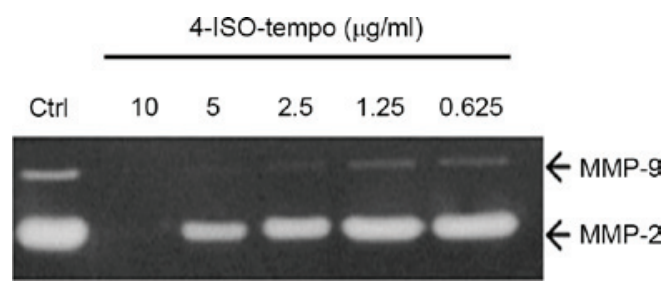

Figure 3. 4-ISO-Tempo inhibits enzymatic activity of matrix metalloproteinase (MMP)-2 and MMP-9 in human microvascular endothelial cell 1. The experiment was repeated three times. 4-ISO-Tempo, 4-isothiocyanate-2, 2, 6, 6-tetramethyl piperidinooxyl.

Effect of 4-ISO-Tempo on endothelial cell viability. Since the growth of tumor cells is closely correlated with angiogenesis, we investigated the effect of 4-ISO-Tempo on the cell viability of endothelial cells. As shown in Fig. 2, 4-ISO-Tempo treatment for 24 or $72 \mathrm{~h}$ inhibited the cell viability of HMEC-1 cells, with $\mathrm{IC}_{50}$ values of 4.668 and $1.386 \mu \mathrm{g} / \mathrm{ml}$, respectively. Although 4-ISO-Tempo also inhibited the growth of a variety of tumor cells, the $\mathrm{IC}_{50}$ values demonstrated that endothelial cells were more sensitive than tumor cells to 4-ISO-Tempo. Moreover, we concluded that treatment with 4-ISO-Tempo below the concentration of $5 \mu \mathrm{g} / \mathrm{ml}$ for $24 \mathrm{~h}$ did not inhibit cell viability of HMEC-1 cells. Therefore, the following experiments on the anti-angiogenic effects on HMEC-1 cells were performed with 4-ISO-Tempo below the concentration of $5 \mu \mathrm{g} / \mathrm{ml}$ for $24 \mathrm{~h}$.

Effect of 4-ISO-Tempo on enzymatic activity of MMP-2 and MMP-9. Since the degrading of basement membrane and extracellular matrix by MMP secreted from tumor and endothelial cells is crucial for angiogenesis, we analyzed the effect of 4-ISO-Tempo on the secretion of MMP-2 and MMP-9 by HMEC-1 cells. As shown in Fig. 3, 4-ISO-Tempo caused a marked decrease in the secretion of MMP-2 and MMP-9 in a dose-dependent manner. Therefore, it was hypothesized that 4-ISO-Tempo may have the ability to suppress angiogenesis by inhibiting the enzymatic activity of MMP-2 and MMP-9.

Effect of 4-ISO-Tempo on migration of endothelial cells. Since the migration of endothelial cells is involved in angiogenesis and plays a crucial role in the formation of new blood vessels, 
A

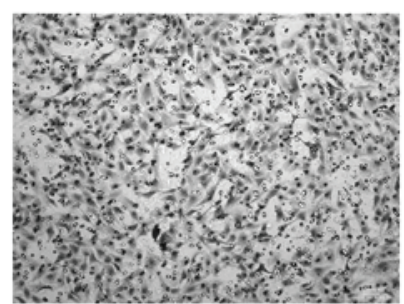

C

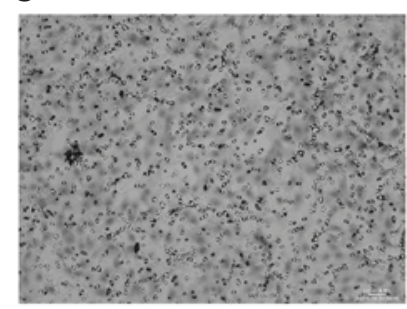

E

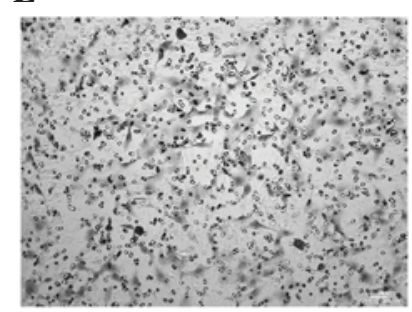

B

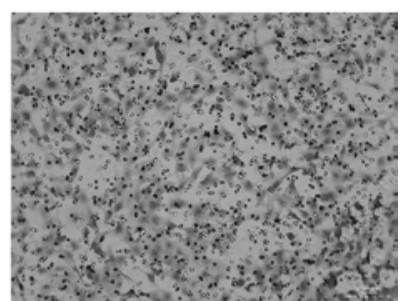

D

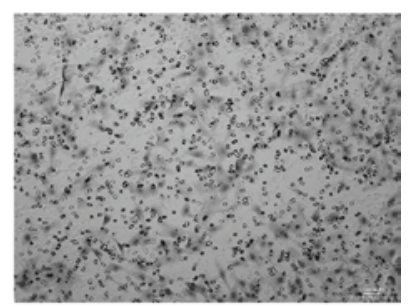

F

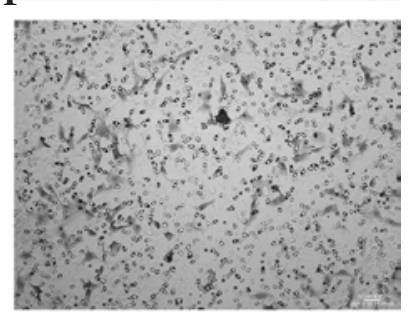

G

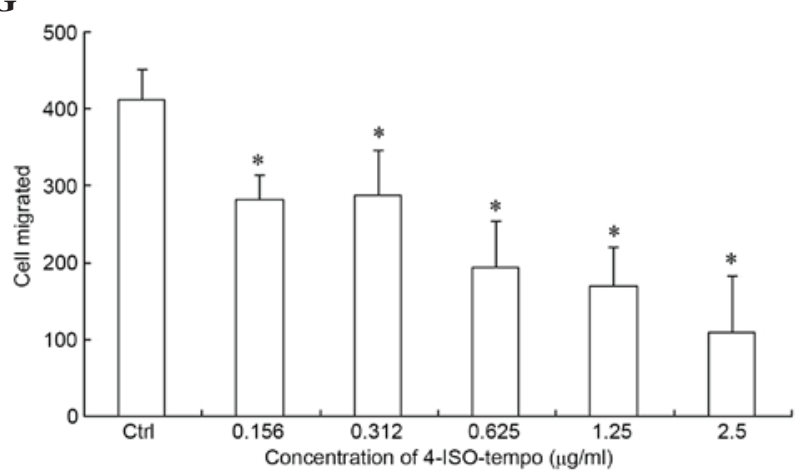

Figure 4. Endothelial cell migration was measured in a Transwell chamber. Cells were pre-treated with various concentrations of 4-ISO-Tempo for $24 \mathrm{~h}$, then non-migrated cells were scraped with a cotton swab. The bottom of the membrane was fixed with methanol and stained with crystal violet. Images from at least five randomly selected microscopic fields were captured (magnification, x100). (A) Control; (B) $0.156 \mu \mathrm{g} / \mathrm{ml}$; (C) $0.312 \mu \mathrm{g} / \mathrm{ml}$; (D) $0.625 \mu \mathrm{g} / \mathrm{ml}$; (E) $1.25 \mu \mathrm{g} / \mathrm{ml}$; (F) $2.5 \mu \mathrm{g} / \mathrm{ml}$. (G) The number of migrated cells was counted. The experiment was repeated at least three times. ${ }^{*} \mathrm{P}<0.05$ vs. control. 4-ISO-Tempo, 4-isothiocyanate-2, 2, 6, 6-tetramethyl piperidinooxyl.

we investigated the effect of 4-ISO-Tempo on endothelial cell migration. As shown in Fig. 4, a large amount of HMEC-1 cells migrated to the lower side of the filter through the Transwell membrane. However, the amount decreased significantly when 4-ISO-Tempo was added to the upper chamber, with inhibition rates of $31.3,29.9,52.8,58.7$ and $73.6 \%$ at concentrations of $0.156,0.312,1.625,1.25$ and $2.5 \mu \mathrm{g} / \mathrm{ml}$.

Effect of 4-ISO-Tempo on tube formation of endothelial cells. Since the differentiation of endothelial cells is required for angiogenesis, we tested the effect of 4-ISO-Tempo on the capillary-like structure formation of endothelial cells.

A

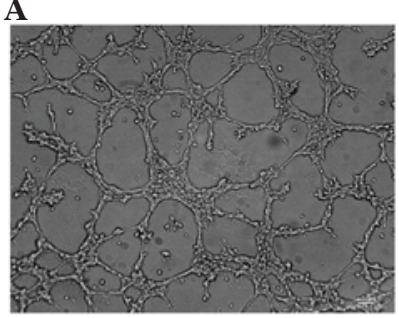

C

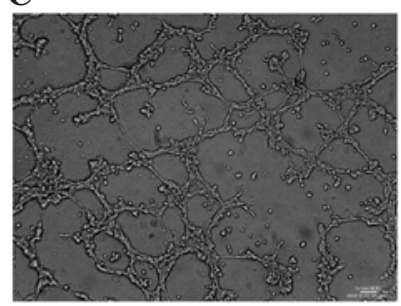

E

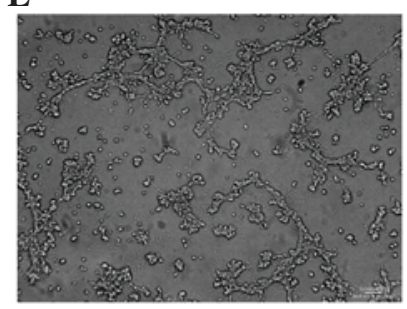

G

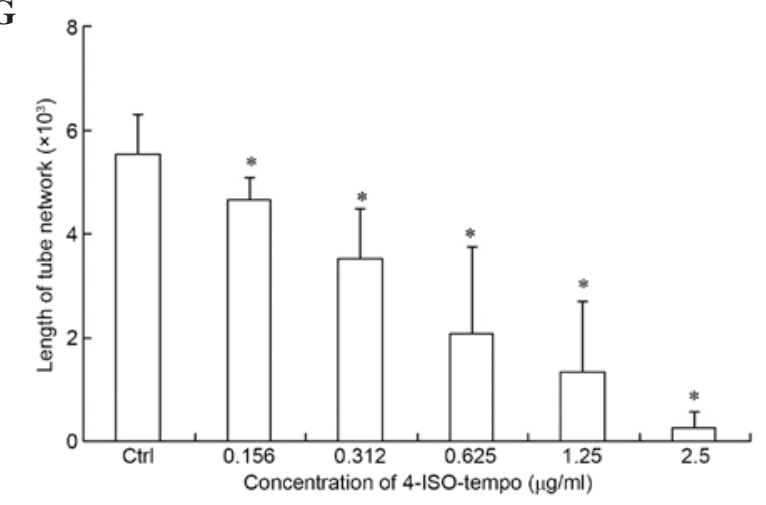

Figure 5. Endothelial cell tube formation assay was measured. Human microvascular endothelial cell 1 cells $\left(8 \times 10^{5}\right.$ cells $\left./ \mathrm{ml}\right)$ were seeded in Matrigel-coated 96-well plates. Cells were treated with various concentrations of 4-ISO-Tempo and incubated for $8 \mathrm{~h}$. (A-F) Representative images of tube formation under a contrast microscope (magnification, x100). (A) Control; (B) $0.156 \mu \mathrm{g} / \mathrm{ml}$; (C) $0.312 \mu \mathrm{g} / \mathrm{ml}$; (D) $0.625 \mu \mathrm{g} / \mathrm{ml}$; (E) $1.25 \mu \mathrm{g} / \mathrm{ml}$; (F) $2.5 \mu \mathrm{g} / \mathrm{ml}$. (G) The length of tube network was measured. The experiment was repeated at least three times. ${ }^{*} \mathrm{P}<0.05$ vs. control. 4-ISO-Tempo, 4-isothiocyanate-2, 2, 6, 6-tetramethyl piperidinooxyl.

The capillary-like structure formation was inhibited by 4-ISO-Tempo with inhibition rates of 15.9, 36.3, 62.3 and $75.9 \%$ at concentrations of $0.156,0.312,0.625$ and $1.25 \mu \mathrm{g} / \mathrm{ml}$. There were no completely formed networks in the $2.5 \mu \mathrm{g} / \mathrm{ml}$ treatment group (Fig. 5).

Effect of 4-ISO-Tempo on VEGFR2 phosphorylation in $H M E C$-1. As a specific mitogen of endothelial cells, VEGF plays a vital role in endothelial cell activation, proliferation, migration and survival by activating VEGF/VEGFR2 signaling cascades (24). To evaluate the molecular mechanism by which 4-ISO-Tempo inhibited angiogenesis, we examined 


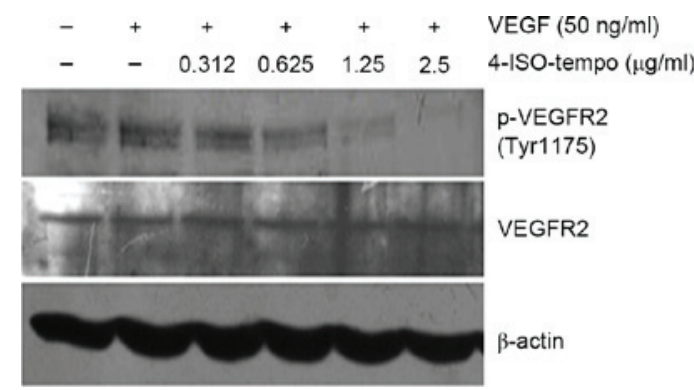

Figure 6. 4-ISO-Tempo inhibits VEGF-induced VEGFR2 phosphorylation. Human microvascular endothelial cell 1 cells were pre-treated with various concentrations of 4-ISO-Tempo for $24 \mathrm{~h}$ and stimulated with recombinant $\operatorname{VEGF}_{165}(50 \mathrm{ng} / \mathrm{ml})$ for $10 \mathrm{~min}$. The experiment was repeated three times. 4-ISO-Tempo, 4-isothiocyanate-2, 2, 6, 6-tetramethyl piperidinooxyl; VEGF, vascular endothelial growth factor; VEGFR2, vascular endothelial growth factor receptor 2 .

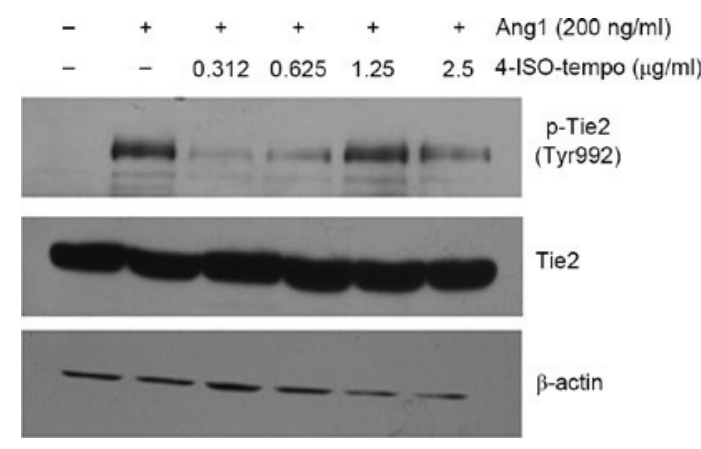

Figure 7. 4-ISO-Tempo inhibited Ang1-induced Tie2 phosphorylation. Human microvascular endothelial cell 1 cells were pre-treated with various concentrations of 4-ISO-Tempo for $24 \mathrm{~h}$ and stimulated with recombinant Ang1 $(200 \mathrm{ng} / \mathrm{ml})$ for $30 \mathrm{~min}$. The experiment was repeated three times. 4-ISO-Tempo, 4-isothiocyanate-2, 2, 6, 6-tetramethyl piperidinooxyl; Ang1, angiopoietin 1 .

its effect on phosphorylation of VEGFR2 stimulated by VEGF. We observed that 4-ISO-Tempo was unable to affect the basal expression of VEGFR2, while it strongly blocked phosphorylation of VEGFR2 at Tyr 1175 in a dose-dependent manner after stimulating VEGF165 $(50 \mathrm{ng} / \mathrm{ml})$ for $10 \mathrm{~min}$ (Fig. 6). Our results demonstrated that 4-ISO-Tempo may suppress angiogenesis by interrupting VEGF-induced VEGFR2 phosphorylation.

Effect of 4-ISO-Tempo on Tie2 phosphorylation in HMEC-1. Ang1 mediates vessel maturation and integrity by favoring the recruitment of pericytes and smooth muscle cells (25). During angiogenesis, Ang1 is able to induce the phosphorylation of Tie2, which is subsequently able to transduce a biological signal to endothelial cells (25). As shown in Fig. 7, Ang1 $(200 \mathrm{ng} / \mathrm{ml})$ treatment induced phosphorylation of Tie2 at Tyr 992 significantly, while 4-ISO-Tempo blocked the phosphorylation of Tie2 at all concentrations. Our results demonstrated that 4-ISO-Tempo may inhibit angiogenesis by blocking Ang1-induced Tie2 phosphorylation.

Effect of 4-ISO-Tempo on ROS generation of endothelial cells. We subsequently investigated the effect of 4-ISO-Tempo on ROS generation in HMEC-1 cells. As shown in Fig. 8,

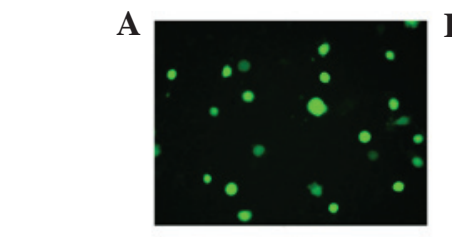

C
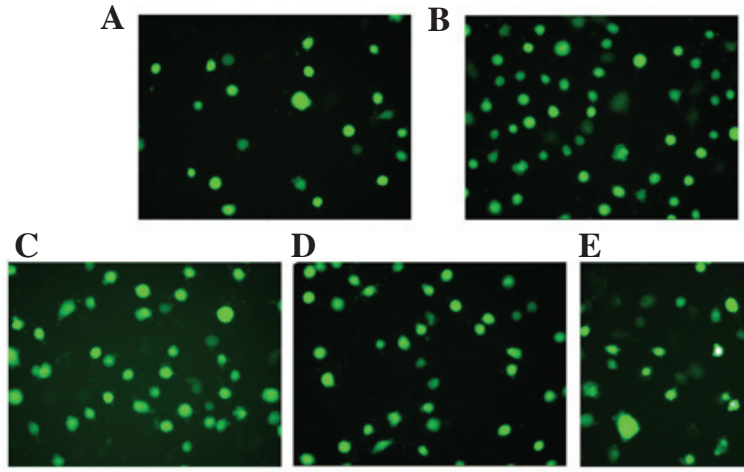

E

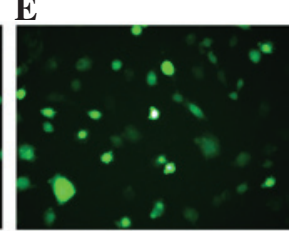

$\mathbf{F}$

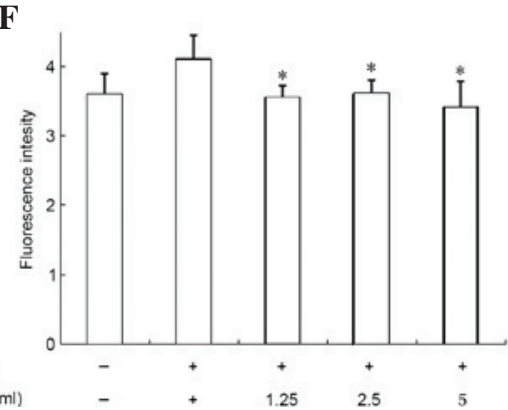

Figure 8. Effect of 4-ISO-Tempo on VEGF-induced reactive oxygen species (ROS) was examined with DCFH-DA as a fluorescence probe. Human microvascular endothelial cell 1 cells were pre-treated with various concentrations of 4-ISO-Tempo for $4 \mathrm{~h}$ and stimulated with recombinant $\operatorname{VEGF}_{165}(50 \mathrm{ng} / \mathrm{ml})$ for $10 \mathrm{~min}$ and then incubated with DCFH-DA $(10 \mu \mathrm{M})$ for an additional $30 \mathrm{~min}$. Representative photos of ROS fluorescence level under a contrast fluorescence microscope (x400). (A) control; (B) VEGF; (C) $\mathrm{VEGF}+1.25 \mu \mathrm{g} / \mathrm{ml}$; (D) $\mathrm{VEGF}+2.5 \mu \mathrm{g} / \mathrm{ml}$; (E) $\mathrm{VEGF}+5 \mu \mathrm{g} / \mathrm{ml}$. (F) Fluorescence intensity was measured. The experiment was repeated at least three times. ${ }^{*} \mathrm{P}<0.05$ vs. control. 4-ISO-Tempo, 4-isothiocyanate-2, 2 , 6, 6-tetramethyl piperidinooxyl; VEGF, vascular endothelial growth factor; DCFH-DA, 2',7'-Dichlorofluorescin diacetate.

treatment with VEGF increased intracellular ROS production, while 4-ISO-Tempo decreased this VEGF-induced effect. Therefore, it was hypothesized that 4-ISO-Tempo inhibited endothelial cell growth, migration and tube-like formation by reducing ROS generation.

\section{Discussion}

Tumor angiogenesis is essential for the growth of solid tumors, since tumors remain in the dormant phase for a long time in the absence of the initiation of blood vessel formation. Usually, the tumor mass diameter does not exceed 1-2 mm without involving angiogenesis, and this is the size limit for simple diffusion of nutrients and oxygen (1). Therefore, the angiogenesis process could be an significant target in suppressing tumor growth and metastasis. There are numerous complex steps involved in angiogenesis, including basement membrane degradation, migration, proliferation and formation of capillary tubes of endothelial cells. Endothelial cells are the main players in the angiogenesis process and could be a particular target for anti-angiogenic therapy. Our results revealed that 4-ISO-Tempo significantly inhibited A549 and SW620 cell viability. In addition, 4-ISO-Tempo markedly inhibited the proliferation of HMEC-1 cells in a concentration-dependent manner, and the effective concentration of 4-ISO-Tempo in 
HMEC-1 cells is much lower than that in A549 and SW620 cells. This suggests that endothelial cells are more sensitive to 4-ISO-Tempo than tumor cells.

Endothelial cells release MMPs, a family of proteinases, to degrade the extracellular matrix for their migration during the sprouting process in vivo $(26,27)$. The breakdown of the tissue matrix by MMPs to facilitate the movement of newly formed endothelial cells for vessel formation is a critical step in angiogenesis (28). MMP-2 and MMP-9 are overexpressed in invasive prostate cancer, and facilitate the invasion of tumor and endothelial cells $(27,29)$. 4-ISO-Tempo notably reduced the secretion of MMP-2 and MMP-9. In addition, it significantly inhibited the migration and capillary-like structure formation of endothelial cells in a concentration-dependent manner in vitro. This indicated that 4-ISO-Tempo suppressed neovascularization through a multi-step process in vitro.

During initial angiogenesis and vasculogenesis, a variety of growth factors and cytokines are upregulated, and exert their functions through autocrine or paracrine actions. Of these, VEGF is the most significant mitogenic and survival factor for vascular endothelial cells, since its receptors are selectively located in endothelial cells (30). There is now considerable evidence that VEGFR2 is the main mediator of VEGF-driven responses in endothelial cells, and it is considered to be a crucial signal transducer in physiological and pathological angiogenesis. The VEGF binds to VEGFR2, leading to receptor dimerization and phosphorylation at Tyr 1175, which has been identified as a major autophosphorylation site and is critical in mediating migratory responses $(31,32)$. Our results demonstrated that 4-ISO-Tempo had no effect on the expression of VEGFR2, whereas it strongly inhibited phosphorylation of VEGFR2 at Tyr 1175 after stimulating VEGF for $10 \mathrm{~min}$.

The activation of Tie2 promotes endothelial cell migration and survival as well as the maturation of new blood vessels. Blockade of the Ang1/Tie2 and VEGF/VEGFR2 signaling pathways strengthened the anti-VEGF therapy efficacy on angiogenesis $(33,34)$. In our study, we observed that 4-ISO-Tempo blocked the phosphorylation of Tie2 at Tyr 992 after stimulating Ang1 $(200 \mathrm{ng} / \mathrm{ml})$ for $30 \mathrm{~min}$. These results demonstrated that 4-ISO-Tempo not only inhibited the phosphorylation of VEGFR2 but also the phosphorylation of Tie2, indicating that 4-ISO-Tempo is an anti-angiogenic agent with bifunctional inhibition of sprouting angiogenesis and maturation of blood vessels.

ROS have been suggested as significant mediators of angiogenesis (35). VEGF promotes proliferation and migration of endothelial cells via VEGFR2. ROS are involved in VEGFR2 autophosphorylation and angiogenic-related responses in endothelial cells. A previous study revealed that diphenyleneiodonium, a nicotinamide adenine dinucleotide phosphate-oxidase inhibitor, blocked the phosphorylation of AKT and p44/42 MAPK via inhibition of ROS generation induced by Ang1 (36). In the present study, stimulation with VEGF also induced massive ROS production by endothelial cells. This result is consistent with that of the aforementioned study by Chen et al (36). However, pretreatment with 4-ISO-Tempo significantly inhibited VEGF-induced ROS generation, which indicated that the inhibitory effect of 4-ISO-Tempo on VEGFR2 and Tie2 phosphorylation was attributed to decreasing ROS generation.
4-ISO-Tempo exhibits anti-neoplastic activity in vitro. In addition, 4-ISO-Tempo also inhibits proliferation, migration and tube formation of HMEC-1 cells. These results may be partly attributed to reducing ROS generation and further inhibiting phosphorylation of VEGFR2 and Tie2. The most promising feature of 4-ISO-Tempo is its ability to inhibit VEGFR2 and Tie2 phosphorylation in the VEGF/VEGFR2 and Ang1/Tie2 pathway simultaneously to minimize the possibility of resistance to anti-VEGF therapy in angiogenesis. Although the exact mechanism of anti-angiogenesis of 4-ISO-Tempo remains elusive, we have demonstrated that this agent is a potent inhibitor of angiogenesis, suggesting that 4-ISO-Tempo could be investigated for its usefulness in anti-angiogenesis therapies.

\section{Acknowledgements}

This study was supported by the Medical Foundation of Lanzhou University (LZUYX200617) and research funds obtained from Key Lab of Preclinical Study for New Drugs of Gansu Province (GSKFKT-0702), and partly supported by National Natural Science Foundation of China (30700142).

\section{References}

1. Folkman J: What is the evidence that tumors are angiogenesis dependent. J Natl Cancer Inst 82: 4-6, 1990.

2. Weidner N, Semple JP, Welch WR and Folkman J: Tumor angiogenesis and metastasis - correlation in invasive breast carcinoma. N Engl J Med 324: 1-8, 1991.

3. Macchiarini P, Fontanini G, Hardin MJ, Squartini F and Angeletti CA: Relation of neovascularisation to metastasis of non-small-cell lung cancer. Lancet 340: 145-146, 1992.

4. Smith-McCune KK and Weidner N: Demonstration and characterization of the angiogenic properties of cervical dysplasia. Cancer Res. 54: 800-804, 1994.

5. Ferrara $\mathrm{N}$ and Bunting S: Vascular endothelial growth factor, a specific regulator of angiogenesis. Curr Opin Nephrol Hypertens 5: 35-44, 1996.

6. Jones N, Iljin K, Dumont DJ and Alitalo K: Tie receptors: new modulators of angiogenic and lymphangiogenic responses. Nat Rev Mol Cell Biol 2: 257-267, 2001.

7. Koch AE, Polverini PJ, Kunkel SL, Harlow LA, DiPietro LA, Elner VM, Elner SG and Strieter RM: Interleukin-8 as a macrophage-derived mediator of angiogenesis. Science 258: 1798-1801, 1992.

8. Lu N, Gao Y, Ling Y, Chen Y, Yang Y, Gu HY, Qi Q, Liu W, Wang XT, You QD and Guo QL: Wogonin suppresses tumor growth in vivo and VEGF-induced angiogenesis through inhibiting tyrosine phosphorylation of VEGFR2. Life Sci 82: 956-963, 2008.

9. Zachary I and Gliki G: Signaling transduction mechanisms mediating biological actions of the vascular endothelial growth factor family. Cardiovasc Res 49: 568-581, 2001.

10. Kowanetz M and Ferrara N: Vascular endothelial growth factor signaling pathways: therapeutic perspective. Clin Cancer Res 12: 5018-5022, 2006.

11. Madhusudan S and Ganesan TS: Tyrosine kinase inhibitors in cancer therapy. Clin Biochem 37: 618-635, 2004.

12. Tabernero J, Yoshino T, Cohn AL, Obermannova R, Bodoky G, Garcia-Carbonero R, Ciuleanu TE, Portnoy DC, Van Cutsem E, Grothey A, et al: Ramucirumab versus placebo in combination with second-line FOLFIRI in patients with metastatic colorectal carcinoma that progressed during or after first-line therapy with bevacizumab, oxaliplatin, and a fluoropyrimidine (RAISE): a randomised, double-blind, multicentre, phase 3 study. Lancet Oncol 16: 499-508, 2015.

13. Singh R, Kim WJ, Kim PH and Hong HJ: Combined blockade of HER2 and VEGF exerts greater growth inhibition of HER2-overexpressing gastric cancer xenografts than individual blockade. Exp Mol Med 45: e52, 2013. 
14. Sivonová M, Tatarková Z, Duracková Z, Dobrota D, Lehotský J, Matáková T and Kaplán P: Relationship between antioxidant potential and oxidative damage to lipids, proteins and DNA in aged rats. Physiol Res 56: 757-764, 2007.

15. Peshavariya HM, Liu GS, Chang CW, Jiang F, Chan EC and Dusting GJ: Prostacyclin signaling boosts NADPH oxidase 4 in the endothelium promoting cytoprotection and angiogenesis. Antioxid Redox Signal 20: 2710-2725, 2014

16. Swartz HM: Interactions between cells and nitroxides and their implications for their uses as biophysical probes and as metabolically responsive contrast agents for in vivo NMR. Bull Mag Res 8: 172-175, 1986.

17. Keana JFW, Lex L, Mann JS, et al: Novel nitroxides for spin-labelling, -trapping and magnetic resonance imaging applications. Pure Appl Chem 62: 201-205, 1990.

18. Gariboldi MB, Ravizza R, Petterino C, Castagnaro M, Finocchiaro $G$ and Monti E: Study of in vitro and in vivo effects of the piperidinenitroxide Tempol - a potential new therapeutic agent for gliomas. Eur J Cancer 39: 829-837, 2003.

19. Zhang C, Yang F, Zhang XW, Wang SC, Li MH, Lin LP and Ding J: Grateloupia longifolia polysaccharide inhibits angiogenesis by down regulating tissue factor expression in HMEC-1 endothelial cells. Br J Pharmacol 148: 741-751, 2006.

20. Vichai V and Kirtikara K: Sulforhodamine B colorimetric assay for cytotoxicity screening. Nat Protoc 1: 1112-1116, 2006.

21. Kwak HJ, Park MJ, Park CM, Moon SI, Yoo DH, Lee HC, Lee SH, Kim MS, Lee HW, Shin WS, et al: Emodin inhibits vascular endothelial growth factor-A-induced angiogenesis by blocking receptor-2 (KDR/Flk-1) phosphorylation. Int J Cancer 118: 2711-2720, 2006.

22. Pang X, Yi Z, Zhang X, Moon SI, Yoo DH, Lee HC, Lee SH, Kim MS, Lee HW and Shin WS: Acetyl-11-keto-beta-boswellic acid inhibits prostate tumor growth by suppressing vascular endothelial growth factor receptor 2-mediated angiogenesis. Cancer Res 69: 5893-5900, 2009.

23. Zhuang J, Jiang T, Lu D, Luo Y, Zheng C, Feng J, Yang D, Chen C and Yan X: NADPH oxidase 4 mediates reactive oxygen species induction of CD146 dimerization in VEGF signal transduction. Free Radic Biol Med 49: 227-236, 2010.

24. Kim CW, Son KN, Choi SY and Kim J: Human lactoferrinupregulates expression of KDR/Flk-1 and stimulates VEGF-A-mediated endothelial cell proliferation and migration. FEBS Lett 580: 4332-4336, 2006.
25. Augustin HG, Koh GY, Thurston G, Alitalo K: Control of vascular morphogenesis and homeostasis through the angiopoietin-Tie system. Nat Rev Mol Cell Biol 10: 165-177, 2009.

26. Grant DS and Kleinman HK: Regulation of capillary formation by laminin and other components of the extracellular matrix. EXS 79: 317-333, 1977.

27. Takaha N, Resar LM, Vindivich D and Coffey DS: High mobility group protein HMGI(Y) enhances tumor cell growth, invasion, and matrix metalloproteinase-2 expression in prostate cancer cells. Prostate 60: 160-167, 2004.

28. Overall CM and López-Otín C: Strategies for MMP inhibition in cancer: innovations for the post-trial era. Nat Rev Cancer 2: 657-672, 2002.

29. Mehta PB, Jenkins BL, McCarthy L, Thilak L, Robson CN, Neal DE and Leung HY: MEK5 overexpression is associated with metastatic prostate cancer and stimulates proliferation, MMP-9 expression, and invasion. Oncogene 22: 1381-1389, 2003.

30. Veikkola T and Alitalo K: VEGFs, receptors and angiogenesis. Semin Cancer Biol 9: 211-220, 1999.

31. Ferrara N, Gerber HP and LeCouter J: The biology of VEGF and its receptors. Nat Med 9: 669-676, 2003.

32. Kim SL, Lee ST, Trang KT, Kim SH, Kim IH, Lee SO, Kim DG and Kim SW: Parthenolide exerts inhibitory effects on angiogenesis through the downregulation of VEGF/VEGFRs in colorectal cancer. Int J Mol Med 33: 1261-1267, 2014

33. Huang S, Yang N, Liu Y, Hu L, Zhao J, Gao J, Li Y, Li C, Zhang X and Huang T: Grape seed proanthocyanidins inhibit angiogenesis via the downregulation of both vascular endothelial growth factor andangiopoietin signaling. Nutr Res 32: 530-536, 2012

34. Pyriochou A, Tsigkos S, Vassilakopoulos T, Cottin T, Zhou Z, Gourzoulidou E, Roussos C, Waldmann H, Giannis A and Papapetropoulos A: Anti-angiogenic properties of a sulindac analogue. Br J Pharmacol 152: 1207-1214, 2007.

35. Paeng SH, Jung WK, Park WS, Lee DS, Kim GY, Choi YH, Seo SK, Jang WH, Choi JS, Lee YM, et al: Caffeic acid phenethyl ester reduces the secretion of vascular endothelial growth factor through the inhibition of the ROS, PI3K and HIF-1 $\alpha$ signaling pathways in human retinal pigment epithelial cells under hypoxic conditions. Int J Mol Med 35: 1419-1426, 2015.

36. Chen JX, Zeng H, Lawrence ML, Blackwell TS and Meyrick B: Angiopoietin-1-induced angiogenesis is modulated by endothelial NADPH oxidase. Am J Physiol Heart Circ Physiol 291: H1563-H1572, 2006. 